\title{
SOME COMMENTS ON THE AMUDARYA
}

\section{Sharif Yakibov}

Candidate Of Philological Sciences, Associate Professor, Termez State University, Termez, Uzbekistan

\section{ABSTRACT}

The article highlights different names of the Amudarya's crossings and their role in our ancestors lives. The toponyms Burdaguy, Pardaguy and Alguy located on the right bank of the Surkhan oasis Amudarya have been etymologically analyzed.

KEYWORDS: - Layhun, Amudarya's crossing, Burdaguy, Pardaguy, Alguy, sounds alteration, Andhuy, caravan paths, hotel.

\section{INTRODUCTION}

The events that took place in the history of mankind will not be completely forgotten. To some extent it leaves its mark on life. Toponyms are an important tool in the long-term preservation of Mazi events. Historically, the Amudarya has been called by different names. Most of them have been proven by scientists to be related to historical events or toponyms around the river. However, it is associated with the crossings of the Amudarya (in Uzbek there are such ancient place names as Burdog'uy (guy), Pardaguy (guy), Andhuy and Olg'uy, which require some additional research to determine their connection with this river.)

The first part of the toponyms consists of the words (In the Uzbek language "burdo", "parda", "and", "old" close to the last part of all three in the case of the words guy, g'uy(xuy) components are added.)
The above words as a whole are toponyms located in the Surkhandarya region of the Republic of Uzbekistan, the Republic of Turkmenistan and the neighboring Islamic Republic of Afghanistan near the Amu Darya. "Guy" persian is formed by the word "speak" "guy" component is not used in modern Uzbek literary language. But in Arabic and Persian-Tajik "go'y" component occurs in a series of words.

\section{Methods}

"Burdoguy is on the edge of Jaihun. It is connected to Termez districts. Burdock is a Greek word used in Alexander's time to mean "hotel." In ancient times, there were large sailors. Those who managed to cross the Jaihun. In this Burdoguy, the sultans used to cross the river (teahouse), "[1] - Hafiz Abru writes in "Zubdat at-tavorix" ("Cream of History"). 
CURRENT RESEARCH JOURNAL OF PHILOLOGICAL SCIENCES 2(11):

168-171, November 2021

DOI: https://doi.org/10.37547/philological-crjps-02-11-36

ISSN 2767-3758

(C)2021 Master Journals

Crossref do

gil Google

Accepted $25^{\text {th }}$ November, 2021 \& Published $30^{\text {th }}$ November, 2021

This cross description describes V.V. It was literally translated into Russian by Barthold and into English by V.M. Minorsky. O.D. Chekhovich translated this text from English into Russian.

\section{Results AND DISCUSSIONS}

According to the article "Greek crossing on the Kampirtepa-Amudarya" in the April 9, 2001 issue of the newspaper "Termez Oqshomi", under the leadership of academician Edward Rtveladze conducted a series of archeological excavations around this crossing and studied the findings of Hafiz Abro. The daily says that Hafiz Abro has the following two views on Burdoguy's death: (In the Uzbek language "Burdog'uy (Pardag'uy) Jayhun bo'yidagi, Termiz yaqinidagi joy.) "It existed long before Termez was founded or was built by the great Alexander. Alexander called it "Burdoguy" or "Pardaguy", which means "hospitable house" in Greek. "[2] After long observations, the expedition led by E. Rtveladze confirms the first guess of Hafiz Abro. This means that Burdaguy was the crossing point of the ancient Oxus, which now crosses the Amu Darya, and existed long before the arrival of Alexander the Great. [2]

According to M.E. Masson, the location near the ancient crossing, $30 \mathrm{~km}$ from the city of Termez on the banks of the Amu Darya, has long been called by different names. In ancient times, Avorix or Obroha may have been the Pardagvi Pass, which was formed long before the construction of Termez. [3] In some sources it is referred to as Chochkaguzar, Shurab, Avaril, Obroha, Kampirtepa. From this point of view, we see that place names have changed a lot in history and have been called by different names.

In particular, the term Burdaguy (Pardaguy) was also used in certain periods and later became an archaic word and as a result was called by different names over time. The word "burdoguy" is historically formed on the basis of a combination of two words and a number of phonetic changes. The word "burda" (curtain) in this word is probably an abbreviated form of the Greek word "Pandaheyon". VF Minorsky, who literally translated Hafiz Abro's above thoughts into English, proves that the word "Pandaka" (hotel) is at the root of the word "Pardagoy". [4]

Later, the word " $n$ " in the word changed to " $r$ " and the "ka" at the end of the word fell. Muhammad Rizobek Hoksor, author of the book Muntahab-ullug'at Zubd-ul-lug'at based on the works of Alisher Navoi, writes that the word "burdo" means compliment. [5] Both the words "curtain" and "burdo" are associated with hospitality and courtesy. The second component of the word "pardaguy" - "guy" - has a number of references in the literature. The guy (goy) components found in a number of words of the honest type mentioned above have the following meanings in Persian. The "guy" component means "speaking" and "speaking" in the first place, and the second meaning means the names of things such as balls, balls, and bowls. [6]

On page 530 of the Dictionary of Navoi Works, created in 1972 by P. Shamsiev and S. Ibragimov, this component of "guy" appears in the form of "truthful", "truthful" and is used in the sense of "truthful". In another dictionary, the word "guy", which is formed in the above-mentioned toponyms to the component of goy, is given as "a biblical word meaning" to confuse, to confuse "[7]. Apparently, these words have nothing to do with the components "guy, guy, guy" in the word "burdaguy (guy)". The word "goy", which is close to the word "guy", comes from the Arabic and Persian languages, such as "duogoy, kalimagoy, rostgoy, haqgoy, haqtgoy, khushomadgoy, turkigoy forsigoy" and expresses the speaker's attitude to the basic meaning.

We continue to observe the meaning of this word in 
CURRENT RESEARCH JOURNAL OF PHILOLOGICAL SCIENCES 2(11):

168-171, November 2021

DOI: https://doi.org/10.37547/philological-crjps-02-11-36

ISSN 2767-3758

(C)2021 Master Journals

Crossref do

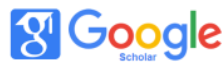

Accepted $25^{\text {th }}$ November, 2021 \& Published $30^{\text {th }}$ November, 2021

connection with the ancient names of the Amudarya. In the past, the Amudarya, which was called by various names, was called by the Chinese term gui-shui at a certain period of history. In toponymy we observe that some terms are referred to in connection with place names. Scientists have found that the toponyms of the Amudarya River, such as the Balkh River, the Termez River, the Kelif River, the Urgench River, and the Khorezm River, have their own names. The word "guy" in the term "guy-shui" is related to the name of the guyshuan tribe. "..... After conquering Dahya (Bactria), the Guishuan ruler Kiotsyukyu subdued the other four rulers and proclaimed himself the Guishuan ruler. [8]

Apparently in history, the country of Guishuan ruled. The word "Guy" is derived from the abbreviation of the name "Guyshuan" of this ruling country, and later changed to the river. It is a transcription of the word "Kushan" in Chinese. (S.Tursunov 2017, p. 46). Accordingly, the word "guy-shuy" means the river of the Kushans. Another thing: in the works of Hafiz Abro, the word is written in the form of "goy" (Burdogoy), but in the works published in Russian, especially in the above article, it is also found in the form "Burdaguy". It is written in the form of a guy in Russian due to the absence of the sound " $g$ '". The word appears as "guy" in texts written by Russian scholars.

The Chinese word "shui" means "water." [9] The word means "river" in Turkish (Z.M. Bobur. Boburnoma.-Tashkent: 1989, p. 5) and in Uzbek and Kyrgyz it means "stream", "valley", "mountain river". "Is used. Accordingly, the word "guy-shui" means "river of the Kushans." [8]

In our opinion, the word "guy-shuy" has been shortened during the historical development and has become a compound word in the form of "guy" and in Burdoguy it has been formed in the form of a hotel near "guy" (river). It is an integral part of the terms "Burdoguy" and "Pardaguy" and is used in the sense of "river hotel".

Another such term is evident in the name of the Olguy dahana of the Khojaikon salt deposit in the present-day Sherabad district, which is located on the border with the neighboring Republic of Turkmenistan and is directly close to the Kelif guzar. The first part of this word is pre- "face." The word is derived from the Old Uzbek word al (a: l) meaning "front" and the Uzbek word "a" formed by the suffix "d" meaning "place". > âld (old). [10] Both the "l, d" sounds at the end of the "old" word are pre-consonantal consonants, and the second consonant at the end of the word is pronounced as a result of a series of two consonant sounds. the consonant sounds down. In linguistics, this is an apocopa phenomenon.

This is especially evident when an addition is made to such words. The consonant "l" in this word is followed by the sound "d". The sound "d" is added to this word with the addition of the back of the tongue "g" and the back of the deep tongue "g". Under the influence of the back row vowel "o", the consonant "g" becomes a deep tongue consonant "g": (front + guy+olguy+olguy). Its pronunciation as "olguy" is also influenced by the bell dialect of the Kipchak dialect living around the gorge of the same name. Based on the above, it can be concluded that the component "goy" was added to the words "burdo, curtain, front" formed by the abbreviation of the Chinese word "guy-shui" in the Amu Darya. The words "Burdoguy" and "Pardaguy" mean a hotel on the banks of the Guyshuan River, and the word "Olguy" means the front of the Guy-Shuy River (the dahana in front of the river).

\section{Conclusion}

The naming of the toponym "Andhuy" (in some sources Andhuy), located in the southern part of the 
CURRENT RESEARCH JOURNAL OF PHILOLOGICAL SCIENCES 2(11):

168-171, November 2021

DOI: https://doi.org/10.37547/philological-crjps-02-11-36

ISSN 2767-3758

(C2021 Master Journals

\section{Crossref do) 81 Google}

Accepted25th November, 2021 \& Published 30 th November, 2021

Amu Darya in the territory of the neighboring Islamic Republic of Afghanistan, is also associated with the above place names. The word is spelled differently in the sources: Anhud, Annhud, Anthud, Nahuz, Nuhuz, Nahud, Anhuz. The "and" part of the word is the same as the "and" in the Andijan word. However, the toponym of Andijan has not been developed yet. Some sources state that the name of the city is related to such seed terms as "andi", adoq, ("azoq"). (National Encyclopedia of Uzbekistan, Volume 1, 2000, p. 323). There are legends that the Andes (Indians) once lived here and the city was called "Andijan". The name of the Andhuy settlement in the territory of the neighboring Islamic Republic of Afghanistan also suggests that a number of such tribes, especially those living in the Andaman Islands of India, are related to the toponym Andhuy. But still the history and etymology of this term require separate research.

\section{REFERENCES}

1. Hofizu Abro'. "Zubdat at-tavorix" (History, cream) // H. Hasanov. "Tourist scientists". Tashkent: "Uzbekistan", 1985, 154 p.

2. "Greek crossing on the KampirtepaAmudarya" // "Clean Evening" newspaper, April 9, 2001 №5 (editor-in-chief's article).

3. Jurabek Chutmatov. The beautiful castles of Termez or the history of Termez (monograph). Tashkent: "YANGI NASHR", 2007, 26-p.

4. E.Rtveladze, B.Turgunov. In search of the paths that Alexander the Great walked. The story of Pardagvi // Excerpts from the history of Termez. Tashkent: Journal of Art, 2008, pp. 20-24.

5. Muhammad Rizobek Khoksar. Dictionary of Alisher Navoi's works. Tashkent: , Akademnashr ", 2017, 270-p.

6. Rubinchik Yu.A. Persian - Russian dictionary.
Tehran: "Publication of Prophecy", 1998.

7. Rubinchik Yu.A. Persian - Russian dictionary. Moscow: 1965.

8. S.Tursunov and b. Toponymic names in Uzbekistan and their history.-Termez, "Surkhan-Nashr", 2017, 46-p.

9. Murzaev E.M. Essays on toponymy.-Moscow: 1974, p-306.

10. Sh.Rahmatullaev. Etymological dictionary of the Uzbek language. Tashkent: „, Universitet ”, 2000, 251-p.

11. Uzbek National Encyclopedia, Tashkent: ("National Encyclopedia of Uzbekistan") State Scientific Publishing House, 2000. 1 vol. $323 \mathrm{~b}$.

12. Sh. Safarov, I.Umarov History of some toponyms. Karshi: Nasaf Publishing House, 2005, p.

13. Muqimovich, Yoqubov Sharif. "Use of Interactive Methods in Teaching Historical Topics in Primary School Reading Lessons." JournalNX: 326-329.

14. Sharif, Y., \& Dilorom, Y. (2019). Integration in primary education as factor mentality. International Journal of Engineering and Advanced Technology, 9(1), 4854-4856.

15. Yakibova, D. "METHODS FOR ENHANCING THE CREATIVE THINKING OF PRIMARY SCHOOLCHILDREN." Herald pedagogiki. Nauka i Praktyka 1.1 (2021). 